\title{
The effects of ego states on democratic attitudes: Nursing students' opinions of nursing faculty members
}

\author{
Ayla Keçeci ${ }^{1}$ \\ Serpil Çelik Durmuş̧ ${ }^{2}$
}

\begin{abstract}
The aim of this descriptive study is to identify the ego states in the Transactional Analysis Approach for evaluating the interpersonal communication process, as well as the views of the nursing students regarding the democratic attitudes of their instructors. Consequently, the faculty members had democratic attitudes and there was a very high direct correlation between the Nurturing Parent ego state and democratic attitude.
\end{abstract}

Keywords: Democratic attitude, Transactional Analysis, Ego state, Nursing

\section{Introduction}

In democratic systems, the education that is provided is in keeping with the principles and rules of democracy and human rights and is learned through experience. Democratic education, a basic condition of a democratic society, is not defined as an active education that is organized with regard to people's races, genders, or different points of views; rather, individual comprehension capacity and personalities are respected, ethical values are kept alive, student participation is encouraged, and rote learning is avoided. Democracy is secured to the extent that citizens internalize it and adopt it as a way of life (Karatürk, 2001; Hotaman, 2010).

Today, one of the primary objectives of education is to guide students through critical thinking, questioning, and discussion skills at all stages of education. Relevant studies show that students' achievement of these skills is likely by means of a democratic approach to education. Democratic attitudes and values are not inherited but can be learned, and the education process needs to be structured in order for a qualified democratic system to flourish (Karahan et al., 2006; Karadağ et al., 2006). Students and educators are the building blocks of education programs. An increase in individuals' adoption of democratic values is only possible when educators have first

\footnotetext{
${ }^{1}$ R.N., Ph.D., Duzce University/School of Health, Nursing Department, aylakececi@gmail.com

2 M.D., Istanbul University, Florence Nightingale Faculty of Nursing, Nursing Management Department, serpilcelik2010@gmail.com
} 
Keçeci, A., \& Çelik Durmuş, S. (2015). The effects of ego states on democratic attitudes: Nursing students' opinions of nursing faculty members. International Journal of Human Sciences, 12(2), 1602-1611. doi:10.14687/ijhs.v12i2.3284

internalized these values (Genç and Kalafat, 2008). A democratic education culture is necessary for the experience and improvement of democracy. In such a culture, the educators' relationships with the students should be free from oppression and fear (Şimşek et al., 2006). The youth who adopt democratic values in the light of educators' democratic attitudes will make the democratic system stronger and more sustainable (Teyin, 2009).

University education has a significant role in the process of young people, who are the potential human power of the future, gaining democratic personalities and making the society democratic (Bingöl, 2000; Teyin, 2009). Young university graduates can make it possible to spread scientific knowledge, thoughts, and attitudes to a vast majority of the public. Therefore, there is a significant connection between the democratization of universities and the democratization of the society (Teyin, 2009). However, studies conducted in Turkish universities reported that faculty members' classroom management was not sufficiently democratic (Erdem and Sarıtaş, 2012; Kumral, 2009). Democratic attitudes and values can only be learned through efficient communication between educators and students.

With respect to nursing education and the profession's theoretical information (Aka, 2001; Velioğlu, 1994), nursing students are being trained to have ethical values, such as respect for human dignity; to treat everyone equally without discriminating in terms of race, language, religion, or religious sect; and to be honest (Fry, 2000). In this sense, democratic attitudes securing individuals' mutual rights and freedoms under equal conditions are most likely to be appreciated in the field of nursing. The environment in which nurses are trained needs to be structured in a democratic way in order to help nurses to adopt democratic attitudes and behaviors. The primary condition for the creation of a democratic environment is the provision and maintenance of healthy communication with students (Aka, 2001; Velioğlu, 1994).

Theories of communication can be utilized to evaluate communication between educators and students. For example, Eric Berne's analytical model, Transactional Analysis (TA), is a humanistic method used in psychology, communication, development, psychopathology, education, and counseling (Akbağ, 2000; Akkoyun, 2007; Kayalar, 2004; Shirai, 2006). The TA approach comprises the following components: Ego States, Transactions, Strokes, Life Scenario, Life Positions, and Time Structures (Akkoyun, 2007; Berne, 1988; Shirai, 2006; Solomon, 2003; Steiner, 2006). The research used in this study is based on ego states, the most basic concept of TA (Akkoyun, 2007), and is described below.

\section{Ego states}

Berne (1988) defined ego states as a consistent pattern of feelings and thoughts that are relevant to a pattern of behavior. Ego states are examined using two separate models-structural 

nursing faculty members. International Journal of Human Sciences, 12(2), 1602-1611. doi:10.14687/ijhs.v12i2.3284

and functional. According to structural analysis, every individual's personality is separated into three states: Parent, Adult, and Child. According to functional analysis, the Parent ego state is separated into the Critical Parent and the Nurturing Parent; the Child ego state into the Free Child and the Adapted Child; and the Adult ego state remains the same (Akbağ, 2000; Akkoyun, 2007; Drego, 2006; Solomon, 2003). The Critical Parent relies on the thoughts, feelings, and beliefs that are learned from parents or parental figures (Solomon, 2003). The Nurturing Parent is protecting and guarding (Akkoyun, 2007). The Adult ego state accurately processes the data that are heard, seen, or thought; suggests solutions to the problems; and evaluates the existing data without biased thoughts or feelings (Solomon, 2003).

The Free Child takes care of a person's physical needs, is spontaneous, does whatever he or she feels like doing, is active and creative, and is the uneducated side of the personality (Akbağ, 2000; Akkoyun, 2007; Dökmen, 2004). The Adapted Child is the part of the personality that develops from parental messages that are learned while growing up (Solomon, 2003).

In this study, assuming that sense of democratic education is learned only if educators communicate effectively with students, the ego states and nursing students' opinions of faculty members' democratic attitudes were correlated.

\section{Method and material}

\section{Purpose and Design}

This descriptive study aims to identify nursing students' opinions of faculty members' democratic attitudes and ego states and to describe the relationship between the two patterns of behavior. This is the first study which is investigated correlation between ego states and democratic attitudes.

\section{Population and Sample Selection}

The sample included 175 students studying in a School of Health Sciences in Turkey. However, the sample comprised a total of 125 students in their first, second, and third year who agreed to participate in the study. The senior students were not involved in the study due to their internship training and limited interaction with faculty members.

\section{Data collection tools}

In the research, three forms were used for data collection. The first aimed to collect data about some of the students' sociodemographic information; the second, the 'Democratic Attitude Scale,' sought to identify faculty members' democratic attitudes; and the third form was the 'Ego States Questionnaire'. On the 'Democratic Attitude Scale', developed by Duman and Koç (2004), the options indicating students' perception levels regarding faculty members' democratic attitudes 

nursing faculty members. International Journal of Human Sciences, 12(2), 1602-1611. doi:10.14687/ijhs.v12i2.3284

and behaviors were rated according to a 5-point Likert Scale as never (1), rarely (2), sometimes (3), often (4), and always (5). The scale had 28 items and the Cronbach Alpha calculated for this scale was .96. Because the scale fives one strong item without rotation, it is considered as single factor. As the total point of the scale increases, the democratic attitude behaviors also increase. Another data collection instrument was 'The Ego States Questionnaire,' which is a list of 95 adjectives that describe human qualities. The questionnaire has a five-point scale, from 0 to 4 . For every ego state, a total raw score is determined. This raw score is then used to divide the highest raw score obtained from the subscales. The calculated raw scores are then added to obtain the total score. Next, the calculated raw scores are divided by the total score to obtain the ego states score (Akbağ, 2000; Arr, 1989). The Cronbach Alpha value calculated for the Ego States Questionnaire was .87.

\section{Data collection place}

A total of 15 professors were teaching in the school during the academic year in which the study was carried out. After being informed about the aim of the study, the questionnaire about a total of 13 professors-12 female and 1 male-was administered to 125 volunteer students.

\section{Research ethics}

Written permission was obtained from the school administration. The faculty members were informed about the aim and rationale of the study and were asked to participate. All agreed to be assessed by the students. The questionnaires were administered after the students gave oral consent.

\section{Evaluation of Data}

The data were analyzed using the computer, and the methods used were percentage, frequency, mean, and regression.

\section{Hypotheses}

$\mathrm{H}_{0}$ : There is not a linear relationship between the dependent variable (democratic attitude) and the independent variables (Critical Parent, Nurturing Parent, Adult, Adapted Child, Natural Child ego states).

$\mathrm{H}_{1}$ : There is a linear relationship between the dependent variable (democratic attitude) and the independent variables (Critical Parent, Nurturing Parent, Adult, Adapted Child, Natural Child ego states).

\section{Results}

\section{Sociodemographic Characteristics}

A total of $89 \%$ (n: 111 ) of the students were female. Also, $41 \%$ (n: 51 ) of them were firstyear students. While $83 \%$ (n: 103) of the students' mothers were elementary school graduates, 60\% 
Keçeci, A., \& Çelik Durmuş, S. (2015). The effects of ego states on democratic attitudes: Nursing students' opinions of nursing faculty members. International Journal of Human Sciences, 12(2), 1602-1611. doi:10.14687/ijhs.v12i2.3284

(n: 75) of the students' fathers were elementary school graduates. In addition, $82 \%$ (n: 102) of students' families had democratic attitudes. Finally, 50\% (n: 63) of the students enjoyed attending the school.

\section{Ego States Findings}

When the ego states that the faculty members used during instruction/the educational process were examined, it was found that they used the Adult state the most and the Adapted Child ego state the least (Graph 1).

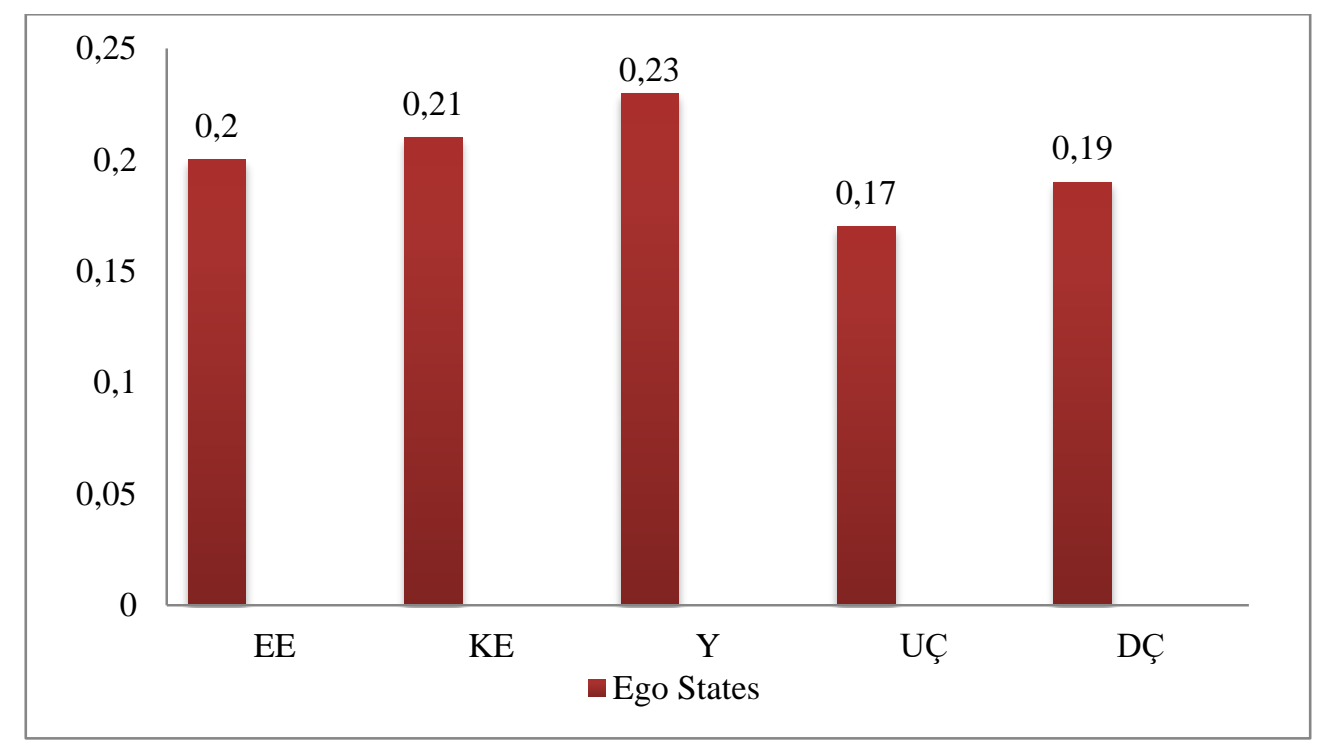

Graph 1. Faculty Members' Ego States

When the faculty members' democratic attitudes were evaluated, it was found to be $\mathrm{X} \pm \mathrm{SD}$ $=3,96 \pm, 78$ (Min: 1, Max: 5). In other words, faculty members had democratic attitudes most of the time.

A standard method was used for regression between faculty members' ego states and students' opinions of democratic attitudes. According to this, there is a moderate linear relationship $\left(\mathrm{R}^{2}=, 558, \mathrm{p}<, 001\right.$; Adjusted $\left.\mathrm{R}^{2}=, 551 \mathrm{p}<, 001\right)$ between Nurturing Parent, Adult, Adapted Child, and Natural Child ego states and democratic attitudes. In other words, 55\% of the changes in democratic attitudes can be explained by four ego states. When other ego states in the applied model were fixed, the correlation between the Nurturing Parent ego state and democratic attitudes was positively very high $(\beta=, 726, \mathrm{p}:, 000)$. According to this result, with regard to democratic attitudes, as nursing faculty members' sample behaviors involved in the Nurturing Parent ego state increase, students' perceptions of democratic attitude are positively affected. 
Keçeci, A., \& Çelik Durmuş, S. (2015). The effects of ego states on democratic attitudes: Nursing students' opinions of nursing faculty members. International Journal of Human Sciences, 12(2), 1602-1611. doi:10.14687/ijhs.v12i2.3284

Table 1. Regression between Faculty Members' Ego States and Students' Opinions of Faculty Members' Democratic Attitudes.

\begin{tabular}{|l|c|c|c|c|}
\hline Model 1 & B & SH & $\boldsymbol{\beta}$ & $\mathbf{p}$ \\
\hline Constant & 2,077 &, 941 & &, 361 \\
\hline Nurturing Parent & 10,369 & 1,321 &, 726 &, 000 \\
\hline Adult & 3,416 & 2,539 &, 120 &, 180 \\
\hline Adapted Child & $-2,859$ & 2,271 &,- 093 &, 209 \\
\hline Natural Child & $-2,772$ & 1,517 &,- 151 &, 069 \\
\hline
\end{tabular}

$\mathrm{R}^{2}=, 558(\mathrm{p}<, 001)$, Adjusted $\mathrm{R}^{2}=, 551(\mathrm{p}<, 001)$.

\section{Discussion}

It was found that faculty members used the Adult ego state the most and the Adapted Child ego state the least. This finding is consistent with those of Parveen and Haque (2002), who also suggested that educators used the Adult ego state the most and Adapted Child ego state the least. When studies about communication between nursing faculty members and students are considered, faculty members are expected to reflect behaviours that are in keeping with Adult, Nurturing Parent and Natural Child ego states. However, the behaviors included in the Critical Parent and Adapted Child ego states are not preferred (Ulupinar, 1998; Gilmartin, 2001; Walker, 2003; Berg and Lindseth, 2004; Salsali, 2005; Schell, 2006). At the educational institution, the nursing faculty members used the Adult ego state more in comparison with others and used the Adapted Child ego the least. This was considered to be positive in terms of creating effective educational environments.

When the nursing faculty members' democratic attitudes were examined, the students stated that the professors had democratic attitudes most of the time. When the studies carried out in Turkey our country are considered, it is clear that there are several studies on democratic attitude. This is highly promising for a country that is still in the process of internalizing the culture of democracy (Karahan et al., 2006; Tosun, 2001). The fact that the nursing faculty members mostly had democratic attitudes can be attributed to the values and philosophy existing in the nursing profession. As mentioned in international documents, since the nursing profession is based on human dignity and has the responsibility to provide equal care to all individuals from all backgrounds (American Nurses Association, 2010; International Council of Nurses, 2006; Nursing and Midwifery Council, 2008), the finding that the faculty members had democratic attitudes while teaching the students these responsibilities was considered significant in our country, where democratic rights and freedoms are currently being discussed (Yavuz, 2009). 
Keçeci, A., \& Çelik Durmuş, S. (2015). The effects of ego states on democratic attitudes: Nursing students' opinions of nursing faculty members. International Journal of Human Sciences, 12(2), 1602-1611. doi:10.14687/ijhs.v12i2.3284

Teaching the culture of democratic life and values is considered to be among the basic duties of schools and curricula. The development of the culture of democratic life depends significantly on the democratization of educational systems. It is extremely important to have students at each education level acquire critical thinking, questioning, and debating skills. Considering the fact that democratic attitudes and values are not inherited but can be learned, it is necessary to state that all societies have equal opportunities (Karahan et al., 2006). With regard to nursing education, nurses are expected to understand the basics about the contemporary information and applications; adopt the lifelong learning principle; and use the new information and skills in the health care of individuals, families, and society. This is owing to reasons such as the fundamental and rapid changes in the healthcare field today, technological improvements, research on improving health and increasing the well-being of individuals, and so on. It is essential for nurses to think critically in order to make decisions on applications and care, not only in daily life but also in theoretical and clinical fields in order to solve problems and to provide sufficient, creative, and effective nursing care. In adapting to new developments and changes, it is necessary to make rational decisions using critical thinking abilities in all the professions in which quick and correct decisions need to be made and applied in the field (Akça, Taşç1 2009). Accordingly, it is of great importance to create democratic environments that support critical thinking and to cultivate a democratic attitude in nursing education while ensuring that the aforementioned qualities are developed. The regression analysis was carried out to determine which ego state was more effective with regard to democratic attitude. In the regression analysis carried out using the standard method, a moderate linear correlation was proven between the Nurturing Parent, Adult, Adapted, and Natural Child ego states and democratic attitudes. Four ego states can explain more than half (56\%) of the changes in democratic attitude. A very high positive correlation exists between the Nurturing Parent ego state and democratic attitude. Therefore, in terms of democratic attitude, as the nursing faculty members' sample behaviors involved in the Nurturing Parent ego state increase, the students' perceptions of democratic attitude are positively affected. As previously mentioned, sample behaviors involved in the Nurturing Parent ego state include being protective, caring, charming, sensitive to others' needs, encouraging, supportive, and incentive (Akkoyun, 2007). When democratic attitudes in the educational environment were studied, similar behaviors—such as freedom from oppression and fear; respect for abilities and thoughts; sensitivity, equality, and lack of discrimination with regard to race or gender (Şimşek et al., 2006)—were observed. In this respect, it is a fact that the correlation between the two variables is inevitable. However, the fact that there is a very high correlation only with the Nurturing Parent is striking, considering that the 
Keçeci, A., \& Çelik Durmuş, S. (2015). The effects of ego states on democratic attitudes: Nursing students' opinions of nursing faculty members. International Journal of Human Sciences, 12(2), 1602-1611. doi:10.14687/ijhs.v12i2.3284

Adult ego state should be used in order to create positive educational environments (Akbağ and

Deniz, 2003; Keçeci and Taşocak, 2009).

\section{Conclusion}

When the nursing faculty members' ego states while teaching were examined, it was found that they used the Adult ego state the most and the Adapted Child the least. In addition, when the democratic attitudes of the nursing faculty members were studied, the faculty members often had democratic attitudes. As mentioned in international documents, since the nursing profession is based on human dignity and has a responsibility to provide equal care to all individuals from all backgrounds (American Nurses Association, 2010; International Council of Nurses, 2006; Nursing and Midwifery Council, 2008), the finding that faculty members had democratic attitudes while teaching the students these responsibilities was considered significant in Turkey, where democratic rights and freedoms are currently being discussed (Demirtaş, 2008; Yavuz, 2009). The analysis of the relationship between ego states and democratic attitudes identified a very high positive correlation between the Nurturing Parent ego state and democratic attitudes. According to this, as the nursing faculty members' sample behaviors involved in the Nurturing Parent ego state increase, the students' perceptions of democratic attitude are positively affected. It is necessary to ensure that the patterns of behavior involved in this ego state become more integrated into educational environments.

\section{References}

Aka, D. K. 2001. Empathy Skills of Nursing Students' in Akdeniz University. Istanbul University Institute of Health Sciences Pyshiatric Nursing Department, Istanbul.

Akbağ, M., 2000. Examination of Some Methods of Coping with Stress in University Students, Negative Automatic Thoughts by Transactional Analysis Ego States and Some Variables. Ph.D. Thesis., Istanbul: Marmara University Institute of Educational Sciences.

Akbağ, M., Deniz, L., 2003. Perceptions of faculty members and student teachers: An evaluation from the aspect of transactional analysis. Educational Sciences: Theory \& Practice 3(2), 263-293.

Akça, Taşç1, 2009. Nursing education and critical thinking. Mersin University Journal of the Faculty of Education 5 (2), 187-195.

Akkoyun, F., 2007. Transactional Analysis. ( $3^{\text {rd }}$ Edition). Nobel Press, Ankara.

American Nurses Association. Position Statement: The Nurse's Role in Ethics and Human Rights: Protecting and Promoting Individual Worth, Dignity, And Human Rights in Practice Settings. 2010, http://nursingworld.org/MainMenuCategories/EthicsStandards/EthicsPosition-Statements/-Nursess-Role-in-Ethics-and-Human-Rights.pdf 
Keçeci, A., \& Çelik Durmuş, S. (2015). The effects of ego states on democratic attitudes: Nursing students' opinions of nursing faculty members. International Journal of Human Sciences, 12(2), 1602-1611. doi:10.14687/ijhs.v12i2.3284

Ar1, R., 1989. University Students' Ego States and Some Characteristics of Ego States Effect on Assertiveness and Level of Adjustment. Ph.D. Thesis, Ankara University Institute of Social Sciences, Ankara.

Berg, C.L., Lindseth, G., 2004. Student's perspective of effective and ineffective nursing instructors. Journal of Nursing Education 43 (12), 565-568.

Berne, E., 1988. What Do You Say After You Say Hello? Bantam Books, 10th Printing, New York.

Bingöl, D., 2000. Young university students with respect to democratic attitudes and values. Journal of Economics and Administrative Sciences 4 (1), 129-157.

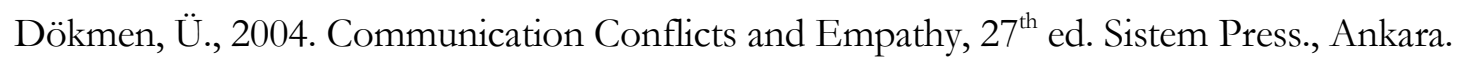

Drego, P., 2006. Why People Say and Do What They Don't Really Want To. http://www.lifepositive.com/mind/psychology/transactional-analysis/harmoniousrelationships.asp

Erdem, A.R., Sartaş, E., 2012. The Classroom Teaching Department Students' Perceptions of How Their Faculty Members' Behaviors are Democratic (PAU Sample). http://www.sosyalbil.selcuk.edu.tr/sos mak/makaleler/Ali $\% 20 \mathrm{R} \% \mathrm{C} 4 \% \mathrm{~B} 1 \mathrm{za} \% 20 \mathrm{ERDEM}$ $\% 20-020 \mathrm{Emel}^{2} \% 20 \mathrm{SARITA} \% \mathrm{C} 5 \%$ E $/$ SARITA $\% \mathrm{C} 5 \% 9 \mathrm{E}, \% 20 \mathrm{Emel} \% 20 \mathrm{vd} .$. pdf

Fry, S.T., 2000. Ethics in Nursing Practice. Translated by: Beyhan Bağ. Aktif Publishing, Erzurum.

Genç, S.Z., Kalafat, T., 2008. A research on the assessment of pre-service teachers' democratic attitudes and emphatic skills. Journal of Social Sciences 19, 211-222.

Gilmartin, J., 2001. Teachers' understanding of facilitation styles with student nurses. International Journal of Nursing Studies 38, 481-488.

Hotaman, D., 2010. Democratic education: A democratic education program. Kuramsal Eğitimbilim 3 (1), 29-42.

International Council of Nurses. The ICN Code of Ethics for Nurses. 2006, http://www.icn.ch/images/stories/documents/about/icncode english.pdf.

Karadağ, E., Baloğlu, N., Yalçınkayalar, P., 2006. A study on a relationship between the teachers' perceptions of elementary school administrators' democratic attitudes and the democratic values of the teachers. Journal of Value Education 4 (12), 65-82.

Karahan, T. F., Sardoğan, M. E., Özkamalı, E. ve Dicle, A. N., 2006. Öğretmen Adaylarında Demokratik Tutum, Nevrotik Eğilimler ve Kendini Gerçekleştirme. Hacettepe University Education Faculty Journal 30, 149-158.

Karatürk, K., 2001. A Way to Become a Democratic, Secular Education Modern Society, An1 Publishing, Ankara.

Kayalar, M., 2004. Evaluation of Manager's Ego State in the Workplace. http://www.sdu.edu.tr.

Kececi, A., Taşocak, G., 2009. Nurse faculty's ego states: Transactional analysis approach. Nurse Education Today 29 (7), 746-752.

Kumral, O., 2009. Pre-service teachers' perceptions about the faculty's behavior. Pamukkale University Journal of Education Faculty 25 (1), 92-102.

Nursing and Midwifery Council. The Code: Standards of Conduct, Performance and Ethics for Nurses and Midwives. 2008, http://www.nmc-uk.org/Documents/Standards/The-codeA4-20100406.pdf. 
Keçeci, A., \& Çelik Durmuş, S. (2015). The effects of ego states on democratic attitudes: Nursing students' opinions of nursing faculty members. International Journal of Human Sciences, 12(2), 1602-1611. doi:10.14687/ijhs.v12i2.3284

Parveen, N., Haque, A.,2002. Sindh üniversitesi kampüsünde sifat tarama listesi yoluyla Transaksiyonel Analiz ego durumlar. Pakistan Psikolojik Araştırmalar Dergisi 17 (3-4), 99-110.

Salsali, M., 2005. Evaluating Teaching Effectiveness in Nursing Education: An Iranian Perspective. BMC Medical Education 5(29), http://www.biomedcentral.com/1472-6920/5/29.

Schell, A.K.,2006. A delphi study of innovative teaching in baccalaurate nursing education. Journal of Nursing Education 45 (11), 439-444.

Shirai, S., How Transactional Analysis Can Be Used in Terminal Care. International Congress Series 1287 , 179-184.

2006. http://www.sciencedirect.com/science/article/pii/S0531513106000070

Solomon, C.,2003. Transactional analysis theory: Basics. Transactional Analysis Journal 33 (1), 1522

Steiner, C., Healing Alcoholism. 09.02.2006. www.emotional-literacy.com/hea2.htm.

Şimşek, U., Doymuş, K., Şimşek, Ü., Özdemir, Y.,2006. The Investigation of the effect of the cooperative learning method on the democratic attitudes of the students at high schools. Journal of Atatürk University Institute of Social Sciences 7 (1), 165-172.

Teyin, Z.,2009. The Democratic Attitudes of the Education Faculty Members Working at Uludağ University. Unpublished Master's Thesis. Bursa: Uludağ University Institute of Social Sciences, Department of Educational Sciences, Curriculum and Instruction.

Tosun, G.,2001. A theoretical and practical approach to the obstacles to the consolidation of democracy in the context of state-Civil society relations in Turkey. Journal of Ege Akademik Bakış 1 (1), 224-243.

Ulupinar, S.,1998. Teachers' Characteristics According to Students and Faculty Members. National Nursing Congress IV with International Participation. Congress Booklet. GATA School of Nursing. Damla Printing, Ankara.

Velioğlu, P.,1994. Hemşireliğin Düşünsel Temelleri. Alaş Ofset Matbaacıllk, İstanbul.

Walker, K. L.,2003. Bridging the Gap in Study-Faculty Interaction: Human Dynamics and Educational Benefits. A Dissertation of Doctor of Philosophy in Education, University of California.

Yavuz, B.,2009. Understanding of pluralistic democracy and human rights. Journal of Gazi University Law Faculty XIII (1-2), 283-302. 